\title{
THE EFFECT OF SALINITY-SODICITY AND GLYPHOSATE FORMULATIONS - AVANS PREMIUM 360 SL ON PHOSPHOMONOESTERASE ACTIVITIES IN SANDY LOAM
}

\author{
Maciej Płatkowski ${ }^{1}$, Arkadiusz Telesiński $^{1}$ \\ 1 Department of Plant Physiology and Biochemistry, West Pomeranian University of Technology in Szczecin, \\ Słowackiego 17, 71-434 Szczecin, Poland, e-mail: maciej.platkowski@zut.edu.pl
}

Received: 2015.11 .20

Accepted: 2015.12.09

Published: 2016.01.06

\begin{abstract}
The aim of study was to determine the influence of $\mathrm{NaCl}$ and glyphosate-based herbicide Avans Premium 360 SL on acid and alkaline phosphomonoesterase activities in sandy loam. The experiment was carried out in laboratory conditions on sandy loam with $\mathrm{C}_{\text {org }}$ content $10.90 \mathrm{~g} / \mathrm{kg}$. Soil was divided into half kilogram samples and adjusted to $60 \%$ of maximum water holding capacity. In the experiment dependent variables were: I - dosages of Avans Premium 360 SL (0, a recommended field dosage - FD, a tenfold higher dosage - $10 \mathrm{FD}$ and hundredfold higher dosage - $100 \mathrm{FD}$ ), II - amount of $\mathrm{NaCl}(0,3 \%$ and $6 \%)$, III - day of experiment $(1,7,14,28$ and 56). On days of experiment the activity of alkaline and acid phosphomonoesterase activity was assayed spectrophotometrically. The obtained result showed that the application of Avans Premium $360 \mathrm{SL}$ decreased in acid and alkaline phosphomonoesterase activity in clay soil. Significant interaction effect between the dosage of Avans Premium 360 SL, $\mathrm{NaCl}$ amount and day of experiment was reported in the experiment. The inhibitory effect of Avans Premium 360 SL was the highest in soil with $\mathrm{NaCl}$ at the amount of $6 \%$.
\end{abstract}

Keywords: soil, glyphosate, salinity, acid phosphomonoesterase, alkaline phosphomonoesterase.

\section{INTRODUCTION}

Glyphosate (N-(phosphonomethyl) glycine), is the active ingredient in herbicide formulations containing it [Zhang et al., 2015]. Indeed, glyphosate or glyphosate formulations are able to kill weeds without killing their crops, especially annual broadleaf weeds and grasses known to compete with commercial crops grown around the globe by interfering with the synthesis of the aromatic amino acids [Kier and Kirkland, 2013; Al Rajabi and Hakami, 2014]. Furthermore, glyphosate formulations are currently marketed in the worldwide by many agrochemical companies, such as Bayer, Dow Agro Sciences, Syngenta, and Monsanto in different solution strengths and with various surfactants and adjuvants [Zhang et al., 2015]. Several studies have reported that the toxicity glyphosate- based herbicides to environment is largely due to surfactants in the mixture [Moore et al., 2012; Uren-Webster et al., 2014].

Glyphosate is applied foliarly, but a significant amount of this herbicide may reach the soil [Lane at al., 2012]. Mostly significant route of glyphosate degradation is decomposition of C-P bond, catalyzed by microbial enzymes: C-P lyase, phosphatases [Forlani et al., 1999].

Saline soils contain a high amount of soluble salts, primarily $\mathrm{Ca}^{2+}, \mathrm{Mg}^{2+}, \mathrm{K}^{+}$, and $\mathrm{Na}^{+}$salt of $\mathrm{Cl}^{-}, \mathrm{NO}_{3}^{-}, \mathrm{SO}_{4}^{2-}$ and $\mathrm{CO}_{3}^{2-}$ [Siddikee et al., 2011]. Salts in soil have a negative impact on soil physical, chemical, and biological properties and can ultimately deteriorate soil quality in both ecological and agricultural aspects. Salinity detrimentally affects microbial communities and their activity in soils, which are important in recycling of nutrients in soil, increase the fertility and 
maintain ecological functions [Rietz and Haynes, 2003, Telesiński et al., 2015].

The aim of study was to determine combined effect of salinity and Avans Premium 360 SL (containing ammonium salt of glyphosate in amounts $360 \mathrm{~g} / \mathrm{dm}^{3}$ ) on soil acid and alkaline phosphomonoesterase activities.

\section{MATERIAL AND METHODS}

Top soil (up to $20 \mathrm{~cm}$ depth) samples were collected from Gumieniecka Plain (53 $24^{\prime}$ N and $\left.14^{\circ} 28^{\prime} \mathrm{E}\right)$. This field remained under conventional farming practices and no history of glyphosate application in the last 3 years The soil samples were sieved through a $2.0 \mathrm{~mm}$ mesh size to remove stones and plant debris. The soil was classified as sandy loam (43\% fraction $1.0-0.1 \mathrm{~mm}$, $30 \%$ fraction $0.1-0.02 \mathrm{~mm}, 27 \%$ fraction $<0,02$ $\mathrm{mm}$ ) with organic $\mathrm{C}$ and total $\mathrm{N}$ content 10.91 and $1.39 \mathrm{~g} / \mathrm{kg}$, respectively.

Sallow components were divided into half kilogram samples and adjusted to $60 \%$ maximum water holding capacity. In the experiment dependent variables were: I - dosages of Avans Premium 360 SL ( 0 , a recommended field dosage - FD, a tenfold higher dosage - 10 FD and hundredfold higher dosage - $100 \mathrm{FD}), \mathrm{II}$ - amount of $\mathrm{NaCl}(0$, $3 \%$ and $6 \%$ ), III - day of experiment $(1,7,14,28$ and 56). The amounts of Avans Premium 360 SL and ammonium salt of glyphosate added into soil are presented in Table 1.

Soil samples were precisely stirred and stored in hermetic polyethylene bags at the temperature of $20^{\circ} \mathrm{C}$ and in a dark place. On the days of experiment activities of alkaline [EC 3.1.3.1] and acid [EC 3.1.3.2] phosphomonoesterase were assayed spectrophotometrically, according to the method of Tabatabai and Bremner (1969) in Margesin (1996) modification. The analyses were carried out using spectrophotometer UV-1800 produced by Shimadzu.

The effects of adding different dosages of Avans Premium 360 SL, different amounts of $\mathrm{NaCl}$ and day of experiment on soil phosphomonoestserase activities was analyzed by threeway ANOVA. To assess least significant differences (LSD), Tukey's test was used. Differences with a $P$ value of $<0.05$ were considered significant. All statistics were done using Statistica 10.0 (StatSoft).

\section{RESULTS AND DISCUSSION}

Sandy loam treatments with herbicide Avans Premium 360 SL and $\mathrm{NaCl}$ caused different changes of acid and alkaline phosphomonoesterase activities. The observed effect depended on herbicide dosage, amount of $\mathrm{NaCl}$ and day of experiment (Figures 1, 2).

Table 1. Amounts of Avans Premium 360 SL and ammonium salt of glyphosate added into sandy loam

\begin{tabular}{|c|c|c|}
\hline Dosage & Amount of Avans Premium 360 SL $\left[\mathrm{mm}^{3} / \mathrm{kg}\right]$ & Amount of ammonium salt of glyphosate [mg/kg] \\
\hline 1 FD & 2.60 & 0.94 \\
\hline $10 \mathrm{FD}$ & 26.00 & 9.40 \\
\hline $100 \mathrm{FD}$ & 260.00 & 94.00 \\
\hline
\end{tabular}

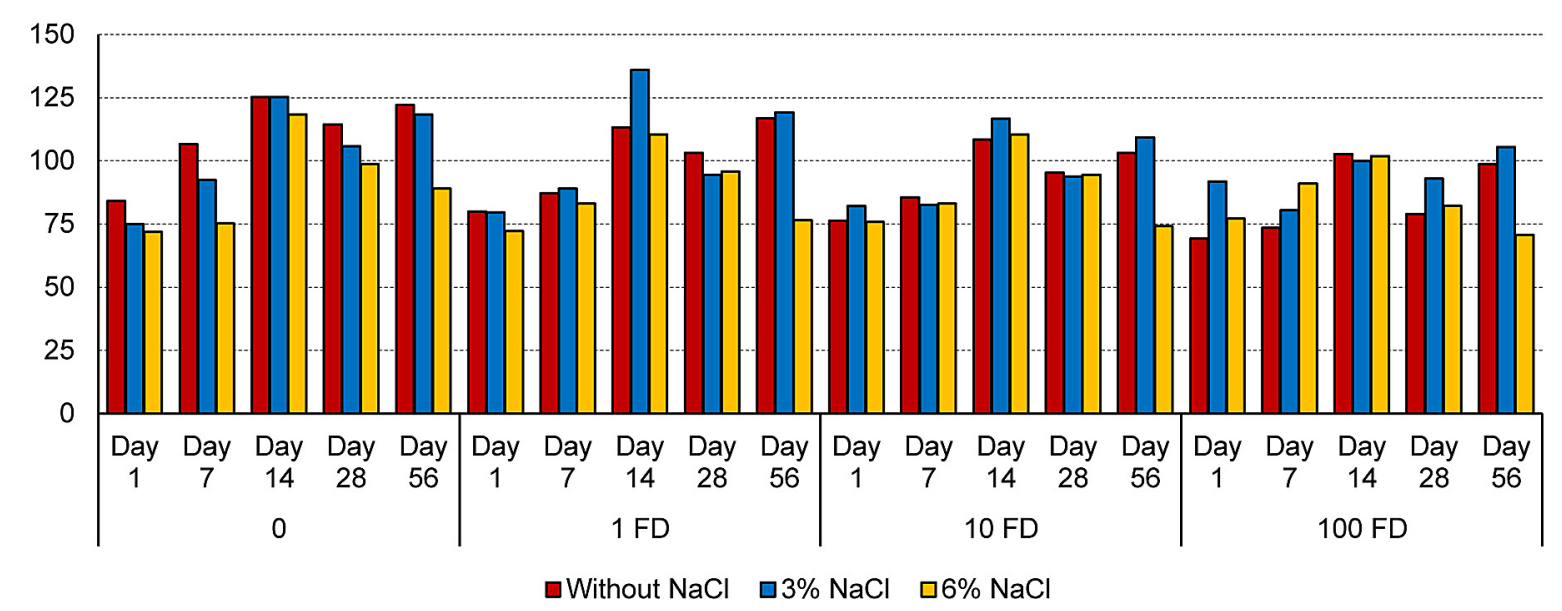

Figure 1. Acid phosphomonoesterase activity (mg p-NP/kg dm/h) in sandy loam treated with herbicide Avans Premium 360 SL and $\mathrm{NaCl}$ 


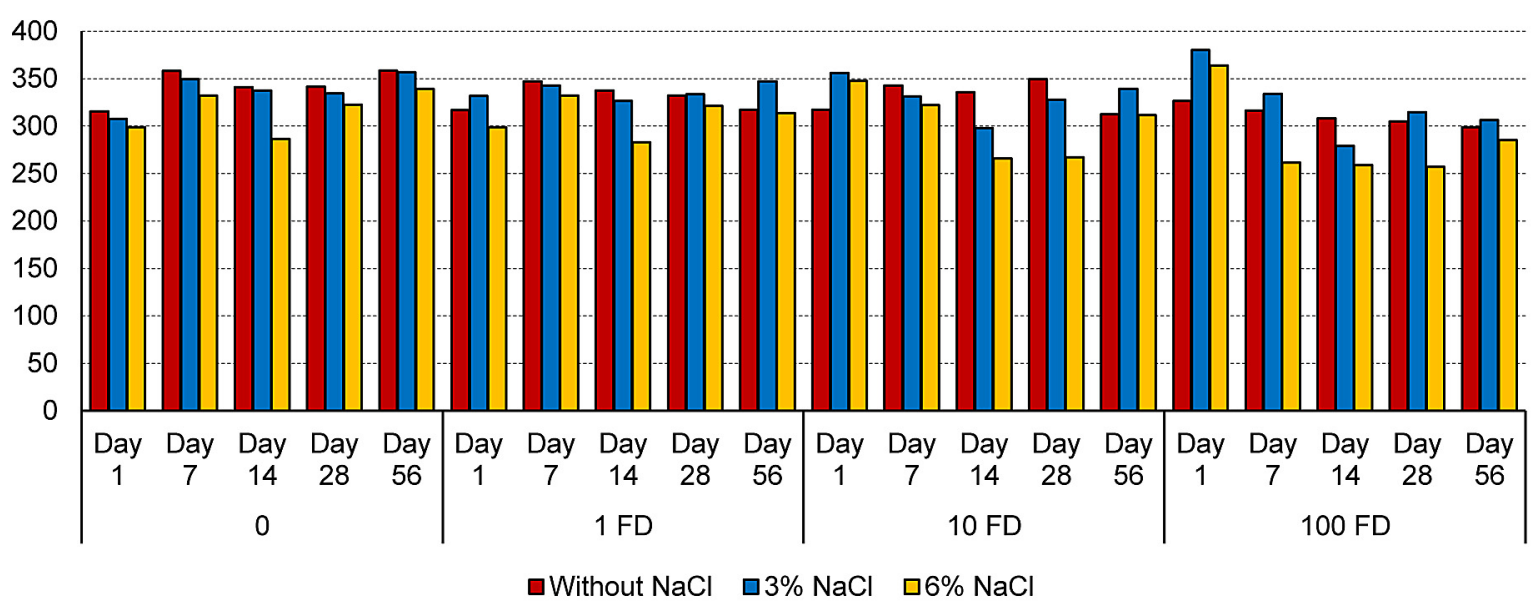

Figure 2. Alkaline phosphomonoesterase activity $(\mathrm{mg} \mathrm{p}-\mathrm{NP} / \mathrm{kg} \mathrm{dm} / \mathrm{h}$ ) in sandy loam treated with herbicide Avans Premium 360 SL and $\mathrm{NaCl}$

A three-way ANOVA showed a significant effect of all treatments on acid and alkaline phosphomonoesterases at $\mathrm{P}<0.05$ (Table 2). After the application of Avans Premium 360 SL the inhibition of acid and alkaline phosphomonoesterase was reported. This effect increased with increase of herbicide decrease (Table 3). Inhibitory effect of glyphosate-based formulations on enzymes involved in phosphorus metabolism in soil was noted in previous studies [Sannino and Gianfreda, 2001; Płatkowski and Telesiński, 2015a; Płatkowski and Telesiński, 2015b]. Speir and
Ross [1978] indicate that inhibition of phosphomonoesterases due to the presence in the glyphosate molecule phosphonate group. Moreover, according Ying et al. [2011] acid phosphomonoesterase activity could be used as an indicator of microbial glyphosate biodegradation. However, stimulation of phosphomonoesterases in soil with glyphosate was also observed by Nakatani at al. [2014] and Cherni et al. [2015].

Treatments with sodium chloride in amount of $6 \%$ decreased activity of phosphomonoesterases (Table 3). Other researchers also indi-

Table 2. F-statistics of three-way ANOVA of the effects of Avans Premium $360 \mathrm{SL}, \mathrm{NaCl}$ and day of experiment on phosphomonoesterase activities in sandy loam

\begin{tabular}{|c|c|c|c|}
\hline Source of variation & $D F$ & MS & $F$ \\
\hline \multicolumn{4}{|c|}{ Acid phosphomonoesterase } \\
\hline Dosage of herbicide $(A)$ & 3 & 1554.07 & $117.18^{*}$ \\
\hline Amount of $\mathrm{NaCl}(\mathrm{B})$ & 2 & 2404.36 & $181.30^{*}$ \\
\hline Day of experiment (C) & 4 & 6895.72 & $519.97^{*}$ \\
\hline$A \times B$ & 6 & 324.84 & $24.48^{*}$ \\
\hline$A \times C$ & 12 & 192.84 & $14.54^{*}$ \\
\hline$B \times C$ & 8 & 726.35 & $54.77^{*}$ \\
\hline$A \times B \times C$ & 24 & 104.18 & $7.86^{*}$ \\
\hline Error & 120 & 13.26 & - \\
\hline \multicolumn{4}{|c|}{ Alkaline phosphomonoesterase } \\
\hline Dosage of herbicide $(A)$ & 3 & 5321.16 & $58.83^{*}$ \\
\hline Amount of $\mathrm{NaCl}(\mathrm{B})$ & 2 & 14571.95 & $161.10^{*}$ \\
\hline Day of experiment (C) & 4 & 4180.13 & $46.21^{*}$ \\
\hline$A \times B$ & 6 & 294.34 & $3.25^{*}$ \\
\hline$A \times C$ & 12 & 3237.53 & $35.79^{*}$ \\
\hline$B \times C$ & 8 & 2079.09 & $22.00^{*}$ \\
\hline$A \times B \times C$ & 24 & 670.84 & $7.42^{*}$ \\
\hline Error & 120 & 90.45 & - \\
\hline
\end{tabular}

\footnotetext{
* significant at $\mathrm{P}<0.05$.
} 
Table 3. Mean activity of phosphomonosterases in sandy loam treated with Avans Premium $360 \mathrm{SL}$ and $\mathrm{NaCl}$

\begin{tabular}{|c|c|c|}
\hline Factor & $\begin{array}{l}\text { Acid phosphomonoesterase } \\
{[\mathrm{mg} \mathrm{p}-\mathrm{NP} / \mathrm{kg} \mathrm{dm} / \mathrm{h}]}\end{array}$ & $\begin{array}{c}\text { Alkaline phosphomonoesterase } \\
{[\mathrm{mg} \mathrm{p}-\mathrm{NP} / \mathrm{kg} \mathrm{dm} / \mathrm{h}]}\end{array}$ \\
\hline \multicolumn{3}{|c|}{ Dosage of Avans Premium SL } \\
\hline 0 & $101.50 \mathrm{~d}$ & $332.07 \mathrm{c}$ \\
\hline $1 \mathrm{FD}$ & $97.11 \mathrm{c}$ & $325.58 \mathrm{~b}$ \\
\hline $10 \mathrm{FD}$ & $92.74 \mathrm{~b}$ & $321.70 \mathrm{~b}$ \\
\hline $100 \mathrm{FD}$ & $87.80 \mathrm{a}$ & $306.46 \mathrm{a}$ \\
\hline \multicolumn{3}{|c|}{ Amount of $\mathrm{NaCl}$} \\
\hline 0 & $97.26 \mathrm{~b}$ & $329.00 \mathrm{~b}$ \\
\hline $3 \%$ & $99.51 \mathrm{c}$ & $331.83 \mathrm{~b}$ \\
\hline $6 \%$ & $87.95 \mathrm{a}$ & $303.53 \mathrm{a}$ \\
\hline \multicolumn{3}{|c|}{ Day of experiment } \\
\hline 1 & 77.93 a & $330.14 \mathrm{c}$ \\
\hline 7 & $85.81 \mathrm{~b}$ & $330.96 \mathrm{c}$ \\
\hline 14 & $114.02 \mathrm{e}$ & $304.88 \mathrm{a}$ \\
\hline 28 & $95.86 \mathrm{c}$ & $317.29 \mathrm{~b}$ \\
\hline 56 & $100.31 \mathrm{~d}$ & $323.99 \mathrm{c}$ \\
\hline
\end{tabular}

Values denoted by the same letters within a column do not differ statistically.

cated, that under laboratory conditions, salinity negatively influenced enzyme activity in soil, although the level of inhibition varied depending on the kind of analyzed enzyme and soil type [Ahmad and Khan, 1988; Rietz and Haynes, 2003; Telesiński 2012]. Inhibition of enzyme activity in saline soils could be due to the osmotic dehydration of the microbial cells that liberate intracellular enzymes, which become vulnerable to the attack by soil proteases, with a consequent decrease in enzyme activity. The salting-out effect modifies the ionic conformation of the protein-enzyme active site, and specific ionic toxicity causes nutritional imbalance for microbial growth and subsequent enzyme synthesis [Telesiński et al. 2015]. However, the application of $\mathrm{NaCl}$ in the amount of $3 \%$ caused a significant increase of acid phosphomonoesterase activity in soil (Table 3).

These findings were also expressed by a significant interaction effect of dosage of Avans Premium 360 SL vs. $\mathrm{NaCl}$ amount. Further, there was a significant interaction effect between herbicide dosages and salinity vs. day of experiment (Table 2). In soil with $\mathrm{NaCl}$, especially at amounts of $6 \%$ the decrease effect of Avans Premium 360 SL on phosphomonoesterases was mainly higher than in soil without salt. Telesiński et al. [2015] found that soil salinity intensified the negative effect of cadmium on phosphomonoesterases activity in the sandy loam.

\section{CONCLUSIONS}

1. Application of glyphosate-based herbicide Avans Premium 360 SL decreased acid and alkaline phosphomonoesterase activity in sandy loam.

2. Significant interaction effect between the dosage of Avans Premium 360 SL, NaCl amount and day of experiment was reported in the experiment. Application of $\mathrm{NaCl}$ in the amount of $3 \%$ increased acid phosphomonoesterase activity. The effect of the day of experiment was unclear.

3. The inhibitory effect of Avans Premium 360 $\mathrm{SL}$ was the highest in soil with $\mathrm{NaCl}$ at the amount of $6 \%$.

\section{REFERENCES}

1. Ahmad I., Khan K.M. 1988. Studies on enzymes activity in normal and saline soils. Pak. J. Agric. Res. 9, 4, 506-508.

2. Al Rajabi A.J., Hakami O.H. 2014. Behavior of the non-selective herbicide glyphosate in agricultural soil. Am. J. Environ. Sci. 10, 2, 94-101.

3. Cherni A.E., Trabelsi D., Chebil S. Barchoumi F., Rodriguez-Llorente I.D., Zribi K. 2015. Effect of glyphosate on enzymatic activities, Rhizobiaceace and total bacteria; communities in an agricultural Tunisian soil. Water Air Soil Pollut. 226, 145-155. 
4. Forlani G., Mangiagalli A., Nielsen E., Suardi C.M. 1999. Degradation of the phosphonate herbicide glyphosate in soil: evidence for a possible involvement of unculturable microorganisms. Soil Biol. Biochem. 31, 991-997.

5. Kier L.D., Kirkland D.J. 2013. Review of genotoxicity studies of glyphosate and glyphosate-based formulations. Crit. Rev. Toxicol. 43, 283-315.

6. Lane M., Lorenz N., Saxena J., Ramsier C., Dick R.P. 2012. The effect of glyphosate on soil microbial activity, microbial community structure, and soil potassium. Pedobiologia 55, 335-342.

7. Margesin R. 1996. Acid and alkaline phosphomonoesterase with the substrate p-nitrophenyl phosphate. In: F. Schinner, E. Öhlinger, E. Kandeler, R. Margesin (Eds.) Methods in soil biology. Berlin. Springer Verl., 213-217.

8. Moore L.J., Fuentes L., Rodgers Jr. J.H., Bowerman W.W., Yarrow G.K., Chao W.Y., Bridges Jr. W.C. 2012. Relative toxicity of the components of the original formulation of Roundup to five North American anurans. Ecotoxicol. Environ. Saf. 78, 128-133.

9. Nakatani A.S., Fernandes M.F., de Souza R.A., da Silva A.P., dos Ris-Junior F-.B., Mendes I.C., Hungria M. 2014. Effects of the glyphosate-resistance gene and of herbicides applied to the soybean crop on soil microbial biomass and enzymes. Field Crop. Res. 62, 20-29

10. Płatkowski M., Telesiński A. 2015a. Effect of different glyphosate salts on phosphodiesterase and phosphotriesterase activities in soil with reference to ecological importance of soil pollution. A laboratory experiment. Environ. Protect. Natur. Res. 26, 2, 9-14.

11. Płatkowski M., Telesiński A. 2015b. Wpływ glifosatu w postaci soli amonowej na zawartość fosforu przyswajalnego i aktywność wybranych fosfataz w glebie lekkiej. Inż. Ekol. 43, 115-121.

12. Rietz D.N., Haynes R.J. 2003. Effect of irrigation- induced salinity and sodicity on soil microbial activity. Soil Biol. Biochem. 35, 9, 845-854.

13. Sannino F., Gianfreda L. 2001. Pesticide influence on soil enzymatic activities. Chemosphere 45, 417-425.

14. Siddikee M.A., Tipayno M.A., Kim K., Chung J., Sa T. 2011. Influence of varying of salinity-sodicity stress on enzyme activities and bacterial population of Coastal soils of Yellow Sea, South Korea. J. Microbiol. Biotechnol. 21, 4, 341-346.

15. Speir T.W., Ross D.F. 1978. Soil phosphatase and sulphatase. In: R.G. Burns (Ed.) Soil enzymes. Academic Press. Londyn, 197-250.

16. Tabatabai M.A., Bremner J.M. 1969. Use of pnitrophenyl phosphate for assay soil phosphatase activity. Soil Biol. Biochem. 1, 4, 307-310.

17. Telesiński A. 2012. Wpływ zasolenia na wybrane biochemiczne wskaźniki żyzności gleby [The effect of salinity on some biochemical indices of soil fertility]. Woda-Środ.-Obsz. Wiej. 12, 1, 209-217.

18. Telesiński A., Stręk M., Śnioszek M. 2015. Effects of cadmium and salinity-sodicity on acid and alkaline phosphatase activity with reference to ecological importance of soil pollution. Folia Pomer. Univ. Technol. Stetin., Agric., Aliment., Pisc., Zootech. 316, 33, 107-116.

19. Uren-Webster T.M., Laing L.V., Florance H., Santos E.M. 2014. Effect of the glyphosate and its formulations, Roundup, on reproduction in zebrafish (Danio renio). Environ. Sci. Technol. 48, 1271-1279.

20. Ying Y., Haijun Z., Qixing Z. 2011. Using soil available $P$ and activities of soil dehydrogenase and phosphatase as indicators for biodegradation of organophosphorus esticide methamidophos and glyphosate. Soil Sedim. Contam. 20, 688-701.

21. Zhang C., Hu X., Luo J., Wu Z., Wang L., Li B., Wang Y., Sun G. 2015. Degradation dynamics of glyphosate in different types of citrus orchard soils in China. Molecules 20, 1161-1175. 